\author{
Anna Kopacz \\ Uniwersytet Marii Curie-Skłodowskiej w Lublinie \\ ORCID - 0000-0001-5534-3674
}

\title{
POSTAWY ZAWODOWE NAUCZYCIELI A ICH MOTYWACJA OSIĄGNIĘĆ
}

\begin{abstract}
Streszczenie: Częstotliwość i moc motywu osiągnięć dla różnych grup społecznych jest różna, zestawiona z postawami zawodowymi okazuje się ciekawym tematem badań wśród nauczycieli. Celem podjętych badań było ustalenie zależności między postawami wobec pracy nauczycieli a ich motywacją osiągnięć. Badania przeprowadzono w lutym 2016 roku wśród 118 nauczycieli pracujących w Szkole Podstawowej nr 40 im. Leona Kruczkowskiego w Lublinie oraz Zespole Szkół im. ks. Antoniego Kwiatkowskiego w Bychawie. Do przeprowadzenia badań posłużono się Kwestionariuszem do badania motywacji osiagnięć oraz Kwestionariuszem wskaźników postaw zawodowych (KWPZ). Stwierdzono, że istnieje zależność między postawami wobec pracy badanych nauczycieli a ich motywacją osiągnięć zawodowych. Im wyższy poziom motywacji osiągnięć, tym częściej badani nauczyciele przejawiają pozytywne postawy wobec pracy. Ważna wydaje się motywacja osiągnięć nauczycieli. Podjęte badania mogą stanowić zachętę dla kolejnych badaczy do poszerzenia tematyki motywacji oraz jej determinantów. Otrzymane wyniki badań mogą posłużyć lepszemu zrozumieniu środowiska szkolnego, zrozumieniu reguł oraz mechanizmów kształtujących postawy wobec pracy.
\end{abstract}

Słowa kluczowe: postawy zawodowe, motywacja osiągnięć, nauczyciele, środowisko szkolne

\section{WPROWADZENIE}

Profesjonalizm, kompetencje oraz osobowość tworzą triadę kluczowych cech, którymi powinna odznaczać się osoba piastująca zawód nauczyciela. W dobie postępujących technik informacyjnych, szybkiego stylu życia młody nauczyciel powinien być przygotowany na wiele zmian wymagających jego pracy. Wraz z postępem informacyjnym uwidaczniają się nowe metody nauczania, środki dydaktyczne bądź formy komunikacji. 
W cyklu kształtowania się postaw młodego człowieka niezwykle ważne są emocje. Stanowią one fundament do kreowania się dojrzałej osobowości nauczyciela. Nauczyciel gotowy na postęp, który uwidacznia się również w nauczaniu, powinien być otwarty, by móc zaspokoić ciekawość, charyzmatyczny, by wzbudzał tę ciekawość, oraz kreatywny, by ją uwidocznić. Wzbudzona ciekawość powoduje często poznanie bądź poszerzanie swoich pasji, zainteresowań. Odczucie to jest bodźcem do podjęcia działań, w przypadku szkolnictwa zaś jest to chęć uczestnictwa w zajęciach, projektach. Podczas interesujących zajęć uczniowie doświadczają motywacji, co w rezultacie prowadzi do osiągnięcia lepszych wyników nauczania. Wzbudzenie motywacji u uczniów jest trudnym zadaniem stawianym nauczycielowi, często nieosiąganym, ponieważ brakuje tej motywacji samemu nauczycielowi.

Teoretyczne ujęcia postaw były zaczątkiem tworzenia całego wachlarza definicji empirycznych dotyczących postaw zawodowych. Nie wypracowano jednolitej koncepcji postaw na gruncie teoretycznym, nie ma też zgodności co do ich określenia i interpretacji wobec pracy czy zawodu. „Postawy wobec pracy” a „postawy zawodowe” to synonimy. Jak podaje Ryszard Bera (2003), „innym razem postawy wobec pracy dotyczą wszelkich form działalności ludzkiej, gdy postawy zawodowe odnoszą się do działalności, której podstawą są określone kwalifikacje" (s. 54). Nawet w obrębie danej nauki nie brakuje odmiennych interpretacji oraz różnej klasyfikacji postaw wobec pracy. W wąskim znaczeniu „postawą jest stan gotowości czy nastawienie do pracy lub zawodu, reakcje zadań roli zawodowej, wartości stanowiące odpowiedzialność postaw, wyjaśnienie postaw za pomocą teorii motywacji i zadowolenia lub morale” (s. 54-55). W szerokim zakresie „postawy zawodowe” używane są zamiennie z terminem „stosunek do pracy”, które „interesują się nie tylko czynnościami i zadaniami pracowników, ale także ich stosunkiem do zawodu i społecznego środowiska pracy" (s. 55).

Przedmiotem postawy może być wszystko, co ma lub miało znaczenie ze względu na zaspakajanie ich potrzeb, stanowiąc dla nich wartość pozytywną lub negatywną. Przedmiotem postaw może być więc to „co istnieje obiektywnie lub subiektywnie dla ludzi, co ma lub miało związek z zaspakajaniem ich potrzeb i przez to nabrało dla nich odpowiedniego znaczenia" (Mądrzycki 1977, s. 24).

Zainteresowanie motywacją ludzkiego zachowania przejawiają nie tylko psychologowie. Każda osoba posiada mniemanie na temat motywacji, motywów działania ludzkiego, a pewien zasób poglądów ułatwia nam funkcjonowanie w codziennym życiu. Można zatem zauważyć ścisły stosunek motywacji i emocji. Konstatując, motywacja w literaturze najczęściej przybiera różne formy, jednakże wszystkie obejmują procesy umysłowe, które nas pobudzają, pozwalają na dokonanie wyboru i ukierunkowują nasze zachowanie. 
Pojęcia motywacji zdaniem Jana Strelau i Dariusza Dolińskiego (2008) używa się „zarówno w odniesieniu do stanów, których organizm podejmuje działania ukierunkowane na uzyskanie jakiegoś elementu niezbędnego do normalnego funkcjonowania, jak i wtedy, gdy niczego, co niezbędne do życia, mu nie brakuje" (s. 589). W tym drugim wypadku jednostka stawia sobie cele i chce osiągnąć stan lepszy pod względem subiektywnym od istniejącego.

Dla Philipa G. Zimbardo i in. (2010) motywacja jest więc „ogólnym określeniem wszystkich procesów zaangażowanych $w$ inicjowanie, ukierunkowywanie i utrzymywanie fizycznych i psychicznych aktywności. Wymaga pobudzenia i determinuje jedną z możliwych reakcji, którą uruchomia się w danej sytuacji” (s. 60).

Henry Murray i David McClelland (por. Strelau) byli prekursorami badań dotyczących motywacji osiągnięć za pomocą narzędzia zwanego Testem apercepcji tematycznej (TAT). Zimbardo i in. (2010) potrzebę osiągnięć rozumieją jako „stan umysłu wywołujący psychologiczną motywację dążenia do mistrzostwa lub osiągania trudnych celów” (s. 75). Osoby z silną potrzebą osiągnięć są w obliczu trudności bardziej wytrwałe w dążeniu do celu niż osoby ze słabszą potrzebą osiągnięć. Osoby z silną potrzebą osiągnięć częściej pełnią funkcje przywódcze, szybciej poszukują awansu. Na przykład można wyobrazić sobie dwóch studentów: jeden dążący do sukcesu, mistrzostwa w swojej mocnej stronie, skupiający się na wiedzy i rozwoju swoich umiejętności - czerpie satysfakcję z kolejnych opanowanych materiałów. Natomiast drugi student zorientowany na sferę wykonawczą, zadaniową, koncentruje się na rywalizacji, zaspokajając swoją potrzebę osiągnięć.

Okazuje się, że częstotliwość i moc motywu osiągnięć może być różna, a także, że motyw osiągnięć może przejawiać się wielu dziedzinach życia i jest związany $z$ dążeniem jednostki do postawionych sobie celów. Osoby reprezentujące wysoki motyw osiągnięć skłonne są do wykonania swojej pracy solidniej, natomiast mniejszą wagę przywiązują do nagród, które racjonalnie mogą być wynagrodzeniem za dobrze wykonaną pracę. Dla tej jednostki nie jest ważne samo dotarcie do celu, lecz osiągnięcie czegoś dla nich wartościowego. Osoby o wysokiej motywacji osiągnięć są zazwyczaj dobrymi pracownikami, odnoszącymi wiele sukcesów zawodowych.

Aby lepiej poznać adekwatne miejsca pracy pod względem poziomu motywacji osiągnięć Zimbardo i in. (2010) przedstawili kilka szczegółowych wskazówek:

1. Pracownikom $z$ dużą potrzebą osiągnięć należy przydzielać zadania, które będą dla nich wyzwaniem, ale jednocześnie, by te cele były w zasięgu osiągnięcia.

2. Tym, którzy chcą zaspokoić potrzebę władzy, należy dać możliwość wykazania się, kierowania projektami czy grupami roboczymi.

3. Ludzie potrzebujący przynależności będą się lepiej sprawdzali i czuli w środowisku nastawionym na współpracę, a nie na rywalizację. Należy szu- 
kać możliwości współpracy, a nie stanowisk łączących się z izolowaniem od ludzi.

\section{METODA BADAŃ}

Przedmiotem badań były postawy zawodowe nauczycieli rozpatrywane w kontekście ich motywacji osiągnięć zawodowych. Problemy badawcze sformułowano w postaci pytań dopełnienia:

1. Jakie postawy wobec pracy przejawiają nauczyciele?

2. Jaka jest motywacja osiągnięć nauczycieli?

3. Jaki jest związek między postawami wobec pracy nauczycieli a ich motywacją osiągnięć?

Celem badań jest ustalenie związku między poziomem motywacji osiągnięć badanych a postawami, jakie wykazują nauczyciele względem swojej pracy.

W tak zakreślonych badaniach zmienną zależną są postawy zawodowe nauczycieli szkolnych. Zmienną niezależną zaś tworzy motywacja osiągnięć. W badaniach wykorzystano Kwestionariusz do badania motywacji osiagnięć oraz Kwestionariusz wskaźników postaw zawodowych (KWPZ).

Kwestionariusz do badania motywacji osiągnięć jest modyfikacją kwestionariusza Marii Widerszal-Bazyl, który obejmuje 10 wskaźników badanych za pomocą 30 twierdzeń (Widerszal-Bazyl 1979). Kwestionariusz wskaźników postaw zawodowych (KWPZ) został opracowany przez I. Konecką i służy do badania wskaźników postaw zawodowych. Opiera się na założeniu, że stan zaspokojenia potrzeb człowieka w różnych wymiarach życia zawodowego wyznacza kierunek postawy (im większa satysfakcja, tym bardziej pozytywna postawa i odwrotnie im większe niezadowolenie, tym bardziej negatywna postawa).

W kwestionariuszu uwzględniono stosunek między oczekiwaniami pracownika a stanem rzeczywistym, który ujęto w 12 wskaźnikach. Suma uzyskanych w kwestionariuszu punktów składa się na ogólny wskaźnik postawy zawodowej (ze względu na znak układający się na kontinuum: pozytywna - negatywna).

\section{WYNIKI BADAŃ}

Badania własne zostały przeprowadzone w Zespole Szkół im. ks. Antoniego Kwiatkowskiego w Bychawie oraz Szkole Podstawowej nr $40 \mathrm{w}$ Lublinie im. Leona Kruczkowskiego. Badaniem zostali objęci nauczyciele zatrudnieni w szkole. Wy- 
pełnianie zestawów kwestionariuszowych odbywało się podczas przerw szkolnych, jednak większość nauczycieli preferowała wypełnienie kwestionariuszy w domu.

Dobór osób do grupy badanej był celowy. Nauczyciele objęci badaniem w 81,4\% zatrudnieni byli w mieście, a dla pozostałych $18,6 \%$ miejscem zatrudnienia były również szkoły wiejskie. W badaniu wzięło udział 118 nauczycieli. Zdecydowana większość ankietowanych to kobiety $(82,2 \%)$ w porównaniu z liczbą mężczyzn (17,8\%). Najbardziej liczną grupę stanowili badani znajdujący się powyżej 46. roku życia (37,3\%). Drugą grupą co do wielkości badanych jest grupa znajdująca się w przedziale wiekowym 26-35 lata (30,5\%). Co czwarty respondent znajdował się w wieku od 36 do 45 lat $(25,4 \%)$. Najmniejszy odsetek ankietowanych stanowiły osoby niemające skończonego 25 . roku życia $(6,8 \%)$.

Co trzeci nauczyciel charakteryzował się stażem pracy powyżej 20 lat (33,9\%). Drugą pod względem wielkości grupą, zważywszy na staż pracy, to nauczyciele, którzy odbyli swoją pracę od 5 do 10 lat (16,9\%). Najmniejszy odsetek respondentów stanowiły osoby z najkrótszym stażem pracy $(8,5 \%)$.

Tylko 5 osób pełniło funkcję kierowniczą (4,2\%). Większość badanych nauczycieli deklarowała wykształcenie wyższe magisterskie (89,8\%). Blisko co dziesiąta osoba posiada tytuł licencjata $(8,5 \%)$. Najmniejszy odsetek respondentów stanowią osoby, które mogą przedstawić dyplom ukończenia studiów podyplomowych $(1,7 \%)$.

Ogólny wskaźnik postaw zawodowych uporządkowano w następujące przedziały klasowe: wyniki niskie, opisujące niezadowolenie - uzyskanie $40 \%$ punktów możliwych do uzyskania, wyniki przeciętne - uzyskanie 41-59\% punktów możliwych do uzyskania, oraz wyniki wysokie - uzyskanie $60 \%$ lub więcej punktów możliwych do uzyskania.

Tabela 1. Ogólny poziom postaw

\begin{tabular}{|c|l|r|r|}
\hline Lp. & \multicolumn{1}{|c|}{ Ogólny wskaźnik postaw } & N & \% \\
\hline 1 & Postawy negatywne & 10 & 8,47 \\
\hline 2 & Postawy przeciętne & 46 & 38,98 \\
\hline 3 & Postawy pozytywne & 62 & 52,54 \\
\hline
\end{tabular}

Przyjęty podział służy do dokładniejszego wyodrębniania osób wykazujących skrajne postawy zawodowe (pozytywne, negatywne). Na tej podstawie można przyjąć, że większość nauczycieli prezentuje pozytywne postawy zawodowe $(52,5 \%)$, przy czym blisko $40 \%$ ankietowanych wykazuje przeciętny poziom. Tylko 10 osób deklaruje negatywny stosunek do zawodu nauczyciela. Analiza danych zawartych w tabeli wskazuje, że większość respondentów wykazywało postawy pozytywne. 
Tabela 2. Wskaźniki motywacji osiągnięć

\begin{tabular}{|c|c|c|c|c|c|c|c|}
\hline \multirow[t]{2}{*}{ Wskaźnik } & \multicolumn{2}{|c|}{$\begin{array}{l}\text { Niezadowolenie } \\
\text { (2-4 punktów) }\end{array}$} & \multicolumn{2}{|c|}{$\begin{array}{c}\text { Częściowe } \\
\text { zadowolenie } \\
\text { (5-7 punktów) }\end{array}$} & \multicolumn{2}{|c|}{$\begin{array}{c}\text { Zadowolenie } \\
\text { (8-10 punktów) }\end{array}$} & \multirow[t]{2}{*}{$\begin{array}{c}\text { Średnia } \\
\qquad M\end{array}$} \\
\hline & $N$ & $\%$ & $N$ & $\%$ & $N$ & $\%$ & \\
\hline $\begin{array}{l}\text { Dopasowanie obowiązków pod } \\
\text { względem trudności i obciążeń do } \\
\text { umiejętności i sił }\end{array}$ & 14 & 11,86 & 28 & 23,73 & 76 & 64,41 & 3,72 \\
\hline Proporcja nakładów do efektów & 21 & 17,80 & 39 & 33,05 & 58 & 49,15 & 3,47 \\
\hline $\begin{array}{l}\text { Osiąganie w sposób płynny za- } \\
\text { mierzonego celu (wyniku) }\end{array}$ & 20 & 16,95 & 26 & 22,03 & 72 & 61,02 & 3,73 \\
\hline $\begin{array}{l}\text { Możliwość zmian rozwojowych } \\
\text { w pracy zawodowej }\end{array}$ & 12 & 10,17 & 23 & 19,49 & 83 & 70,34 & 4,01 \\
\hline $\begin{array}{l}\text { Zaspokojenie zainteresowań } \\
\text { zawodowych }\end{array}$ & 18 & 15,25 & 55 & 46,61 & 45 & 38,14 & 3,36 \\
\hline $\begin{array}{l}\text { Możliwość przejawiania } \\
\text { inicjatywy }\end{array}$ & 23 & 19,49 & 40 & 33,90 & 55 & 46,61 & 3,38 \\
\hline Samodzielność działania & 42 & 35,59 & 37 & 31,36 & 39 & 33,05 & 2,96 \\
\hline $\begin{array}{l}\text { Zgodność między oczekiwaniami } \\
\text { a stanem rzeczywistym }\end{array}$ & 19 & 16,10 & 55 & 46,61 & 44 & 37,29 & 3,31 \\
\hline $\begin{array}{l}\text { Zgodność gratyfikacji pracy } \\
\text { z oczekiwaniami (akceptacja } \\
\text { uposażenia) }\end{array}$ & 61 & 51,69 & 39 & 33,05 & 18 & 15,25 & 2,40 \\
\hline Ocena pracy przez przełożonych & 19 & 16,10 & 38 & 32,20 & 61 & 51,69 & 3,55 \\
\hline Możliwość awansu & 42 & 35,59 & 36 & 30,51 & 40 & 33,90 & 3,02 \\
\hline Atmosfera pracy & 10 & 8,47 & 24 & 20,34 & 84 & 71,19 & 3,94 \\
\hline
\end{tabular}

Wskaźniki, które determinowały najwyższy poziom zadowolenia nauczycieli, to: dopasowanie obowiązków pod względem trudności i obciążeń do umiejętności i sił, możliwość zmian rozwojowych w pracy zawodowej oraz atmosfera pracy. Wymienione wyżej czynniki decydują o najwyższym poziomie zadowolenia respondentów.

Natomiast o niezadowoleniu świadczą takie czynniki, jak: ograniczona samodzielność działania, brak zgodności gratyfikacji pracy z oczekiwaniami (akceptacja uposażenia) oraz ograniczenie możliwości awansu.

Ogólny wskaźnik motywacji osiągnięć, uporządkowano w następujące przedziały klasowe: wyniki niskie, opisujące niezadowolenie - uzyskanie 40\% punktów możliwych do uzyskania, wyniki przeciętne - uzyskanie 41-59\% punktów możliwych do uzyskania, oraz wyniki wysokie - uzyskanie $60 \%$ lub więcej punktów możliwych do uzyskania. Przyjęty podział służy do dokładniejszego wyodrębniania osób wykazujących skrajne wartości (niskie, wysokie). 
Tabela 3. Ogólny wskaźnik motywacji osiągnięć

\begin{tabular}{|c|c|c|c|}
\hline Lp. & Ogólny wskaźnik motywacji osiągnięć & $\boldsymbol{N}$ & $\mathbf{\%}$ \\
\hline 1 & Przeciętny poziom motywacji osiągnięć & 112 & 94,92 \\
\hline 2 & Wysoki poziom motywacji osiągnięć & 6 & 5,08 \\
\hline
\end{tabular}

Z analizy danych stwierdza się, że zdecydowana większość badanych nauczycieli wykazuje przeciętny poziom motywacji osiągnięć (94\%), przy czym nieliczne jednostki uplasowały się na poziomie wykazującym dużą motywację osiągnięć (5\%).

Tabela 4. Wskaźniki cząstkowe postaw zawodowych

\begin{tabular}{|c|c|c|c|c|c|c|c|c|}
\hline \multirow{2}{*}{ Lp. } & \multirow{2}{*}{$\begin{array}{c}\text { Wskaźniki cząstkowe } \\
\text { (KWZ) }\end{array}$} & \multicolumn{2}{|c|}{ Niski } & \multicolumn{2}{|c|}{ Przeciętny } & \multicolumn{2}{|c|}{ Wysoki } & \multirow{2}{*}{$\begin{array}{c}\text { Średnia } \\
\qquad M\end{array}$} \\
\hline & & $N$ & $\%$ & $N$ & $\%$ & $N$ & $\%$ & \\
\hline 1 & Poziom aspiracji & 21 & 17,80 & 73 & 61,86 & 24 & 20,34 & 9,66 \\
\hline 2 & Wytrwałość w działaniu & 49 & 41,53 & 43 & 36,44 & 26 & 22,03 & 8,88 \\
\hline 3 & Efekt Zeigernik & 5 & 4,24 & 95 & 80,51 & 18 & 15,25 & 9,88 \\
\hline 4 & Planowanie przyszłości & 12 & 10,17 & 69 & 58,47 & 37 & 31,36 & 10,22 \\
\hline 5 & $\begin{array}{c}\text { Akceptacja odraczania } \\
\text { gratyfikacji }\end{array}$ & 30 & 25,42 & 51 & 43,22 & 37 & 31,36 & 9,51 \\
\hline 6 & $\begin{array}{l}\text { Spostrzeganie wartości } \\
\text { czasu wolnego }\end{array}$ & 6 & 5,08 & 90 & 76,27 & 22 & 18,64 & 10,03 \\
\hline 7 & Samozaufanie & 6 & 5,08 & 96 & 81,36 & 16 & 13,59 & 9,56 \\
\hline 8 & Koncentracja na zadaniu & 64 & 54,24 & 42 & 35,60 & 12 & 10,17 & 7,89 \\
\hline 9 & Brak konformizmu & 42 & 35,59 & 66 & 55,93 & 10 & 8,47 & 8,48 \\
\hline 10 & $\begin{array}{c}\text { Dążenie do uznania } \\
\text { społecznego }\end{array}$ & 10 & 8,47 & 67 & 56,78 & 41 & 34,75 & 10,43 \\
\hline
\end{tabular}

Czynniki świadczące o satysfakcji ankietowanych to: planowanie przyszłości, akceptacja odraczania gratyfikacji oraz dążenie do uznania społecznego. Natomiast wskaźniki powodujące niski poziom motywacji osiągnięć to: wytrwałość w działaniu, koncentracja na zadaniu oraz brak konformizmu.

W analizie zależności zmiennej postaw zawodowych nauczycieli i motywacji osiągnięć tej samej grupy osób należy wspomnieć o ogólnie przyjętym przedziale siły korelacji. Wszystkie uzyskane korelacje, istotne statystycznie, mieszczą się w przedziałach korelacji słabej $(0,1<|r| \leq 0,3)$ lub przeciętnej $(0,3<|r| \leq 0,5)$. 
Tabela 5. Zależności między wskaźnikami motywacji a postawami zawodowymi

\begin{tabular}{|c|c|c|c|c|c|c|c|c|c|c|c|}
\hline \multirow[b]{2}{*}{ Zmienna } & \multicolumn{11}{|c|}{ Korelacje } \\
\hline & $\begin{array}{l}\text { Wskaźnik } \\
\text { ogólny } \\
\text { motywacji }\end{array}$ & KPZ1 & KPZ2 & KPZ3 & KPZ4 & KPZ5 & KPZ6 & KPZ7 & KPZ8 & KPZ9 & KPZ10 \\
\hline $\begin{array}{l}\text { Wskaźnik } \\
\text { ogólny } \\
\text { motywacji }\end{array}$ &, $30^{*}$ &,- 07 &, $22^{*}$ &, 11 &, $37^{\star}$ &,- 08 & ,05 &, $36^{*}$ & ,03 & ,05 &, $22^{*}$ \\
\hline POZ1 & ,01 &,- 09 &, 04 & ,12 &, 02 &, $19^{\star}$ &,$- 27^{\star}$ & ,08 &,- 04 &,- 10 &, 01 \\
\hline POZ2 &, $24^{*}$ &, 10 &, $25^{*}$ &, $16^{*}$ & $24^{*}$ &,- 12 &, 03 &, $28^{*}$ &,- 06 &,- 04 &, 18 \\
\hline POZ3 & ,17 & ,01 & ,15 &, 10 &, $22^{*}$ &,- 04 & ,04 &, $25^{\star}$ &,- 02 & ,02 & ,05 \\
\hline POZ4 &,- 02 &,- 16 &, 02 & ,06 &, 17 &,- 07 &, 08 &, 11 &,$- 18^{\star}$ &,- 07 &, 14 \\
\hline POZ5 & ,14 &,- 01 & ,03 & ,12 &, $23^{*}$ &,$- 22^{*}$ & ,09 &, $29^{*}$ &,- 05 &, 02 &, $22^{\star}$ \\
\hline POZ6 &, $31^{\star}$ &,- 05 &, $21^{\star}$ &, 12 &, $29^{*}$ &, 01 &, 11 &, $35^{\star}$ &, 06 &, 03 &, 13 \\
\hline POZ7 &, $26^{*}$ &,- 00 &, $31^{\star}$ &,- 01 &, $27^{\star}$ &,- 14 & ,09 &, $26^{*}$ &, 11 &, 01 &, 06 \\
\hline POZ8 &, $25^{\star}$ &, 04 & ,12 &,- 10 &, $41^{*}$ &,- 13 &, 10 &, $26^{*}$ & ,01 &, $19^{*}$ &, 15 \\
\hline POZ9 &, $27^{\star}$ &, 12 &, 10 &,- 08 &, 11 &, 04 &,- 08 &, $18^{\star}$ &, $23^{\star}$ &, 13 &, 15 \\
\hline POZ10 &, 18 &,- 11 &, 14 &, 11 &, 25 &,- 00 & ,06 &, $19^{\star}$ &,- 03 &, 03 &, 13 \\
\hline POZ11 &, 04 &,$- 21^{\star}$ &,- 01 &, 00 &, 11 &,- 08 &,- 07 &, 04 &, 08 &, 15 &, 15 \\
\hline POZ12 & ,14 &,- 08 & 08 & ,14 & 15 & 03 & ,14 & ,08 & ,04 &,- 07 & ,08 \\
\hline
\end{tabular}

POZ1 - dopasowanie obowiązków pod względem trudności i obciążeń do umiejętności i sił; POZ2 - proporcja nakładów do efektów; POZ3 - osiąganie w sposób płynny zamierzonego celu (wyniku); POZ4 - możliwość zmian rozwojowych w pracy zawodowej; POZ5 - zaspokojenie zainteresowań zawodowych; POZ6 - możliwość przejawiania inicjatywy; POZ7 - samodzielność działania; POZ8 - zgodność między oczekiwaniami a stanem rzeczywistym; POZ9 - zgodność gratyfikacji pracy z oczekiwaniami (akceptacja uposażenia); POZ10 - ocena pracy przez przełożonych; POZ11 - możliwość awansu; POZ12 - atmosfera pracy. KPZ1 - poziom aspiracji; KPZ2 - wytrwałość w działaniu; KPZ3 - efekt Zeigernik; KPZ4 - planowanie przyszłości; KPZ5 - akceptacja odraczania gratyfikacji; KPZ6 - spostrzeganie wartości czasu; KPZ7 - samozaufanie; KPZ8 - koncentracja na zadaniu; KPZ9 - brak konformizmu; KPZ10 dążenie do uznania społecznego.

Pierwsza zależność, którą można odnotować, dotyczy ogólnego poziomu postaw zawodowych i ogólnego poziomu motywacji osiągnięć nauczycieli $(r=0,30)$. Z uzyskanych danych można wnioskować, że im wyższy poziom postaw zawodowych, tym wyższy jest również poziom motywacji osiągnięć u nauczycieli. Najwyższą odnotowaną zależnością jest korelacja dotycząca postawy zgodności między oczekiwaniami a stanem rzeczywistym, a planowaniem przyszłości $(r=0,41)$. Reasumując, im wyższa postawa zgodności, tym wyższy jest czynnik planowania swojej przyszłości.

Z analizy korelacyjnej można wysunąć kilka wniosków. Im większą możliwość przejawiania inicjatywy mieli badani, tym bardziej wzrastał poziom ogólnej moty- 
wacji $(r=0,31)$. Ogólny poziom motywacji osiągnięć wzrastał również w przypadku wzrostu samodzielności działania $(r=0,26)$, wzrostu zgodności między oczekiwaniami a stanem rzeczywistym $(r=0,24)$, zgodności gratyfikacji pracy z oczekiwaniami $(r=0,27)$. Wskaźnik ogólnej motywacji koreluje także z propozycją nakładów do efektów, gdzie korelacja była również dodatnia $(r=0,24)$. Wskaźnik ogólnego poziomu postaw zawodowych koreluje $\mathrm{z}$ aspektem wytrwałości w działaniu - im wyższy poziom postaw zawodowych, tym wytrwałość $\mathrm{w}$ działaniu jest również wyższa $(r=0,22)$. Analizując dalej ogólny poziom postaw zawodowych, należy zauważyć jeszcze kilka zależności. Im wyższy poziom postaw zawodowych, tym wyższy poziom planowania przyszłości $(r=0,37)$, wyższy poziom samozaufania $(r=0,36)$ oraz wyższy poziom dążenia do uznania społecznego $(r=0,22)$.

Z przeprowadzonej analizy wynika, że im obowiązki są bardziej dostosowane pod względem trudności i obciążeń do umiejętności i sił nauczycieli, tym wyższy poziom akceptacji odraczania gratyfikacji $(r=0,19)$, niższy zaś poziom spostrzegania wartości czasu $(r=-0,27)$. Im wyższe są proporcje nakładów do efektów, tym wyższa wytrwałość $\mathrm{w}$ działaniu $(r=0,25)$, planowanie przyszłości $(r=0,23)$ i poziom samozaufania $(r=0,28)$. Im nauczyciele osiągają w sposób płynny zamierzony cel, tym bardziej skupiają się na planowaniu swojej przyszłości $(r=0,22)$ oraz wzrasta samozaufanie $(r=0,25)$. Zależność ujemną zauważono w aspekcie możliwości zmian rozwojowych w pracy zawodowej oraz koncentracji na zadaniu. Im ta możliwość jest większa, tym koncentracja na zadaniu słabnie $(r=-0,18)$.

Zaspokajanie zainteresowań zawodowych koreluje z czteroma czynnikami motywacji osiągnięć zawodowych. Im bardziej zaspokajane są zainteresowania nauczycieli, tym częściej oni planują swoją przyszłość $(r=0,23)$, wzrasta samozaufanie $(r=0,29)$ oraz dążenie do uznania społecznego $(r=0,22)$. Jednak im bardziej zaspokajane są zainteresowania, tym mniejsza akceptacja przez nauczycieli odraczania gratyfikacji $(r=-0,22)$.

W aspekcie możliwości przejawiania inicjatywy zdiagnozowano korelację z czynnikiem samozaufania. Im większa możliwość przejawiania przez nauczycieli inicjatywy, tym wyższy poziom samozaufania $(r=0,35)$. Korelację dodatnią uzyskano jeszcze dla dwóch aspektów. Im nauczyciel ma większą możliwość przejęcia inicjatywy, tym jest wytrwalszy w swym działaniu $(r=0,21)$ oraz bardziej planuje swoją przyszłość $(r=0,29)$.

Korelację o przeciętnej sile zanotowano w aspekcie samodzielności działania oraz wytrwałości w działaniu. Można więc przyjąć założenie, że im bardziej nauczyciel jest samodzielny w swoich działaniach, tym wyższy stopień wytrwałości w nim wykazuje $(r=0,31)$. Słabszą korelację zdiagnozowano jeszcze $\mathrm{w}$ dwóch aspektach motywacji osiągnięć. Im samodzielność działania jest większa, tym wyższy poziom samozaufania $(r=0,26)$ oraz planowania swojej przyszłość $(r=0,27)$ przejawiali badani. 
Aspekt zgodności między oczekiwaniami a stanem rzeczywistym koreluje z samozaufaniem oraz brakiem konformizmu, uzyskując niską siłę zależności. Im wyższa jest ta zgodność, tym wyższy poziom zaufania $(r=0,26)$ oraz częstszy brak konformizmu $(r=0,19)$. Z porównywalną siłą korelacji występują czynniki zgodności gratyfikacji pracy z oczekiwaniami, z samofaufaniem oraz koncentracją na zadaniu. Im zgodność gratyfikacji jest większa, tym bardziej rośnie poziom samozaufania $(r=0,18)$ oraz koncentracja na zadaniu $(r=23$,).

Kolejnym wnioskiem z uzyskanych wyników badań wskazuje, że im bardziej pozytywna ocena udzielona przez przełożonych, tym bardziej wzrasta poziom planowania swojej przyszłości $(r=0,25)$ oraz poprawia się poziom samozaufania $(r=0,19)$. Ujemną korelację zdiagnozowano w aspekcie możliwości awansu i poziomu aspiracji. Im mniejszy poziom uzyskania awansu, tym mniejszy poziom aspiracji nauczycieli $(r=-0,21)$.

Postawiona hipoteza potwierdziła się, tym samym można stwierdzić, że istnieje zależność między postawami wobec pracy badanych nauczycieli a ich motywacją osiągnięć zawodowych. Im wyższy poziom motywacji osiągnięć zawodowych, tym częściej badani nauczyciele przejawiają pozytywne postawy wobec pracy. Korelacje uzyskano w zakresie przezwyciężania trudności, planowania swojej przyszłości, spostrzegania wartości czasu oraz w aspekcie koncentracji na zadaniu. Analizując zmienne ze względu na czynniki socjodemograficzne, uzyskane wyniki wskazały na różnice w zakresie wieku, płci, stażu i miejsca pracy. Z pozostałymi zmiennymi socjodemograficznymi nie uzyskano różnic istotnie statystycznych.

\section{DYSKUSJA}

Tematykę motywacji osiągnięć rozpatrywali już tacy autorzy, jak Janusz Kirenko i Teresa Zubrzycka-Maciąg (2011). Otrzymane wyniki badań w pełni potwierdzają istniejące już w literaturze przekonanie o zależności między motywacją osiągnięć a poziomem wypalenia zawodowego. Uzyskano i poparto wcześniejszymi badaniami (Golińska, Świętochowski 1998; Tomal 2002) zależność o występowaniu negatywnej, istotnie statystycznej korelacji pomiędzy motywacją osiągnięć a syndromem wypalenia zawodowego.

Kirenko i Zubrzycka-Maciąg (2011) zakresem swoich badań objęli również problematykę postaw zawodowych nauczycieli. Dzięki otrzymanym wynikom badań potwierdziła się hipoteza o zależności między zespołem wypalenia zawodowego badanych nauczycielek a ich postawami zawodowymi. Uzyskane korelacje dotyczyły związków między pełnoobjawowym zespołem wypalenia zawodowego, który był dominujący, a niskim poziomem postawy zawodowej. 
Wnioski z przeprowadzonych badań mogą okazać się przydatne dla osób, które na co dzień pracują w środowisku pedagogicznym lub swoimi zainteresowaniami obejmują tę grupę społeczną. Otrzymane wyniki badań mogą posłużyć lepszemu zrozumieniu środowiska szkolnego, zrozumieniu reguł oraz mechanizmów kształtujących postawy wobec pracy. Ważny wydaje się aspekt motywacji osiągnięć nauczycieli. Uzyskane wnioski pozwalają na głębsze dotarcie w struktury, mechanizmy tworzenia się motywacji oraz istotę motywacji osiągnięć.

Problematyka postaw wobec pracy jest niezwykle szeroka. Przeprowadzone badania mogą być zachętą dla przyszłych badaczy do uszczegółowienia i poszerzania dokonanych badań w zakresie postaw wobec pracy nauczycieli. Tematyka postaw wobec pracy wydaje się nadal aktualna, a przedmiotem kolejnych badań można uczynić poczucie przynależności do określonych grup społecznych.

\section{LITERATURA}

Bańka A., 2005, Motywacja osiągnięć. Postawy teoretyczne i konstrukcja skali do pomiaru motywacji osiagnięć w wymiarze międzynarodowym. Studio PRINT-B, Poznań.

Bera R., 2003, Postawy zawodowe pilotów wojskowych w procesie restrukturyzacji polskich sił zbrojnych. Warszawa, Dom Wydawniczy Bellona.

Federowicz M., Strawiński P., 2014, Struktura czasu pracy nauczyciela. Warszawa, Instytut Badań Edukacyjnych.

Federowicz M., Haman J., Herczyński J., Hernik K., Krawczyk-Radwan M., Malinowska K, Pawłowski M., Stawiński P., Walczak D., Wichrowski A., 2013, Czas i warunki pracy $w$ relacjach nauczycieli. Warszawa, Instytut Badań Edukacyjnych.

Golińska L., Świętochowski W., 1998, Temperamentalne i osobowościowe uwarunkowania wypalenia zawodowego u nauczycieli. „Psychologia Wychowawcza”, 5, t. XLI.

Holy J., 2009, Analiza wpływu optymizmu i motywacji w awans w pracy-perspektywa psychologii pozytywnej. Wrocław, Szkoła Wyższa Psychologii Społecznej Wydział Zamiejscowy.

Kędzierska G., 2012, Kariery zawodowe nauczycieli. Konteksty - wzory - pola dyskusji. Toruń, Wydawnictwo Adam Marszałek.

Kirenko J., Zubrycka-Maciąg T., 2011, Wspótczesny nauczyciel: studium wypalenia zawodowego. Lublin, Wydawnictwo UMCS.

Mądrzycki T., 1997, Psychologiczne prawidłowości kształtowania siępostaw. Warszawa WSiP.

Pakuła M., 2010, Postawy osób starszych wobec edukacji: studium teoretyczno-diagnostyczne. Lublin, Wydawnictwo UMCS.

Strelau J., Doliński D., 2008, Psychologia akademicka. T. 1, Gdańsk, Gdańskie Wydawnictwo Psychologiczne. 
Widerszal-Bazyl M., 1979, Ukierunkowanie motywacji osiagnięć a poziom wykonania pracy, Wrocław, Zakład Narodowy im. Ossolińskich.

Wojcieszke B., 2012, Psychologia społeczna. Warszawa, Wydawnictwo Naukowe Scholar. Zimbardo G.P., Johnson R.L., McCann V., 2010, Psychologia: kluczowe koncepcje. T. 1, Warszawa, Wydawnictwo Naukowe PWN.

\title{
TEACHERS' PROFESSIONAL ATTITUDES \\ AND THEIR ACHIEVEMENT MOTIVATION
}

\begin{abstract}
The frequency and strength of the achievement motive for different social groups is different, juxtaposed with professional attitudes, turns out to be an interesting research topic among teachers. The aim of the study was to determine the relationship between attitudes towards teachers' work and their achievement motivation. The study was conducted in February 2016 among 118 teachers working at Primary School No. 40 Leon Kruczkowski in Lublin and the School Complex Antoni Kwiatkowski in Bychawa. The survey used the Performance motivation questionnaire and the Professional attitude index (KWPZ) questionnaire. It was found that there is a relationship between attitudes towards the work of the surveyed teachers and their motivation for professional achievement. The higher the level of achievement motivation, the more often the surveyed teachers exhibit positive attitudes towards work. The motivation of teacher achievements seems to be important. The undertaken research may be an incentive for subsequent researchers to broaden the subject of motivation and its determinants. The obtained research results can be used to better understand the school environment, understand the rules and mechanisms that shape attitudes towards work.
\end{abstract}

Keywords: professional attitudes, achievement motivation, teachers, school environment 